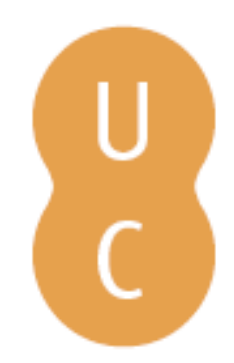

\title{
nombalina
}

\section{Evolution, progress and the confusion of things}
Autor(es): $\quad$ Santos, Ricardo S. Reis dos
Publicado por: Imprensa da Universidade de Coimbra
URL persistente:
URI:http://hdl.handle.net/10316.2/31287
DOI:
DOI:http://dx.doi.org/10.14195/978-989-26-0342-1_14

Accessed : $\quad$ 26-Apr-2023 12:14:36

A navegação consulta e descarregamento dos títulos inseridos nas Bibliotecas Digitais UC Digitalis, UC Pombalina e UC Impactum, pressupõem a aceitação plena e sem reservas dos Termos e Condições de Uso destas Bibliotecas Digitais, disponíveis em https://digitalis.uc.pt/pt-pt/termos.

Conforme exposto nos referidos Termos e Condições de Uso, o descarregamento de títulos de acesso restrito requer uma licença válida de autorização devendo o utilizador aceder ao(s) documento(s) a partir de um endereço de IP da instituição detentora da supramencionada licença.

Ao utilizador é apenas permitido o descarregamento para uso pessoal, pelo que o emprego do(s) título(s) descarregado(s) para outro fim, designadamente comercial, carece de autorização do respetivo autor ou editor da obra.

Na medida em que todas as obras da UC Digitalis se encontram protegidas pelo Código do Direito de Autor e Direitos Conexos e demais legislação aplicável, toda a cópia, parcial ou total, deste documento, nos casos em que é legalmente admitida, deverá conter ou fazer-se acompanhar por este aviso.

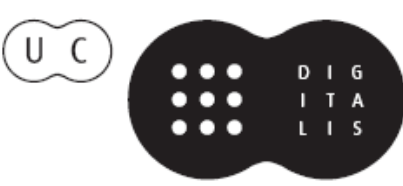


Ana Leonar Pereira João Rui Pita

Pedro Ricarda Fonseca (eds.)
Darwin,

Evalution,

Evolutionisms

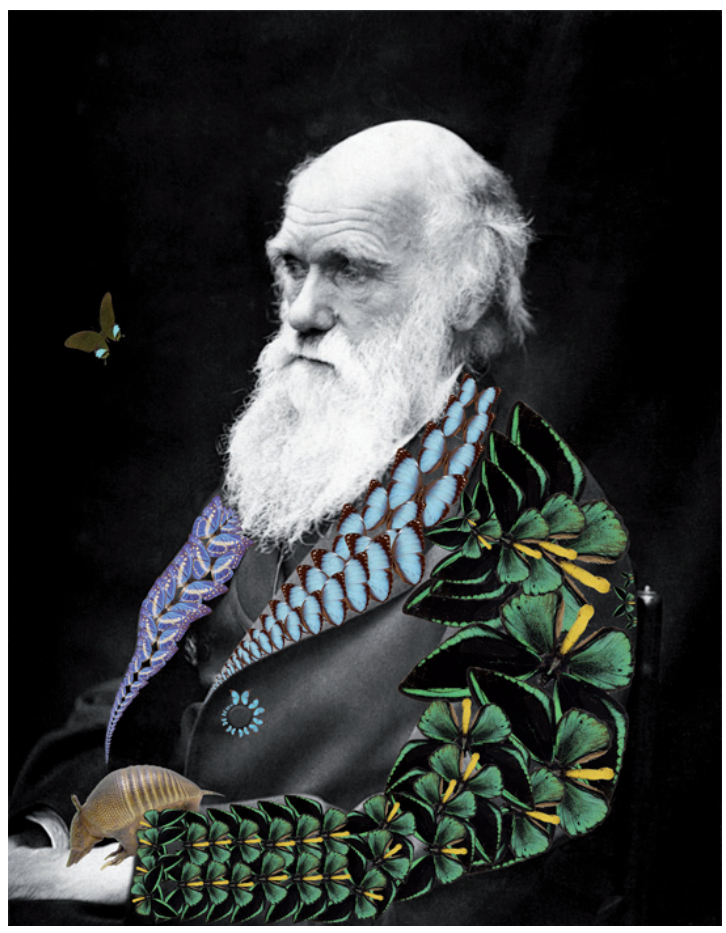


Ricardo S. Reis dos Santos

Centro de Filosofia das Ciências, Faculdade de Ciências, Universidade de Lisboa, Portugal

\section{Evolution, Progress and the Confusion of Things}

\section{Introduction}

In the preface of his book titled Darwin's Dangerous Idea, the North-American philosopher, Daniel C. Dennett writes: «Darwin's evolution theory by means of natural selection always fascinated me but, during the years, I met a surprising variety of thinkers that cannot hide their discomfort towards this great idea and that manifest it with an attitude that goes from persistent skepticism to declared hostility. I found not only laymen and religious men but also secular philosophers, psychologists, physicists and even biologists that would prefer that Darwin was wrong" (Dennett, 1995). This means that evolution is, from its beginning, affected by a certain short-sightedness in relation to its principles and mainly regarding its implications.

Actually, Darwin's ideas challenged, not only all conceptions about the origin of animals and plants, but also about the actual regularity of the world, and mainly the purpose of human life. Victorian society experienced moments of great convulsion. There was a popular conviction that Darwin had murdered the idea of God and that one day, jokingly, had entitled himself the "Devil's chaplain» (Browne, 2006). Thomas Henry Huxley, a close friend of Darwin, gave us a good snapshot of those moments writing in the Westminster Review: «Everyone read the book of Mr. Darwin, or, at least, gave an opinion on his merits or demerits; pietists, whether laymen or ecclesiastic, discredited it...; fanatical devotes denounced it with ignorant censorship; elders, of both genders, considered it a dangerous book, and even wise men... cited antiquated authors to demonstrate that the author is no better than an anthropoid (...)» (Huxley, quoted in Avelar et al., 2004). Rapidly, pamphlets started circulating in the streets ridiculing Darwin, in the cafes lords gathered to give their opinion on the horrendous idea that we all descend from a monkey, in the newspaper cartoons caricatured the origin of the species.

With the publication of The descent of man and selection in relation to sex, in 1871 , the criticism intensified. It was not just the fact that Darwin proposed that living beings should not be considered creations of a divinity, but mainly the fact that this theory took Man off the pedestal of moral superiority. As Browne (2006) noted, «Biblical fundamentalism is mainly a modern concept, and not Victorian. That which Darwinism challenged in the Victorian period was the transformation of life in an amoral chaos, without any sign of divine authority or sense of design 
or purpose». The implications of Darwin's ideas were, in all domains, too profound and affected the fabric of our more fundamental beliefs. The jesuist priest Adam Sedgwick, who had been Darwin's professor when he studied theology at Cambridge, wrote harsh words opposing this theory: «(...) I cannot conclude without expressing my profound rancor for the theory, for its materialism full of determination...; for its total disregard for final causes, indicating an understanding without morality on behalf of its proposers" (Sedwick, 1860, quoted in Avelar et al., 2004). In 1882, an engraving was published in Punch's Almanack illustrating man's evolution, with the inscription that "Man is but a worm». This scenario of a possible origin from a worm insinuated by this almanac with the purpose of causing controversy is a serious thing. Already in the 18th century, when it was suggested that spermatozoids were worms, the Catalan professor Monravá, who taught in the Faculty of Medicine at Campo Santana, used to say to his students: «Sons of worms? This to me is worse than being sons of a bitch!» (Monravá, quoted in Pinto-Correia, 1999).

As François Jacob (1981) said, «the Darwinian conception has, thus, a fatal consequence: the current living world, as we perceive it around us, is just one of many possible. (...) It could just as well be different. It could even not exist.». It is precisely this contingency, this chance, and this vulgarization of the human species that will be controversial. So this is the reason why resistance persisted in time and was mainly assumed as an aspect of absolute truth. Hegel wrote somewhere that humanity will only be satisfied when it lives in a world created by itself. Human solipsism is the most evident face of this resistance.

\section{The march of progress: iconographical overview}

The Swiss naturalist Charles Bonnet (1720-1793) was probably the major enthusiast of Preformation, a theory of reproduction that emerged in the second half of the $17^{\text {th }}$ century and which caused feverous debates among the most brilliant minds of the period. Bonnet dedicated himself to the study of insects and developed, along with René Antoine de Réaumur (1683-1757), an interesting work on parthenogenesis, and ended up by definitively demonstrating that water fleas had «virgin births». With only 25 years of age, Bonnet published a treatise on insectology where he presented the idea of a scale of natural beings. It is curious to note that we can assume this scale as a modified version of Aristotles's scala naturae which is, in the end, a scheme of classification by divisions (diaireses) corresponding to «natural beings». The sequence of these divisions is based on the logic of progression which goes from the simple to the complex, ending with man. 

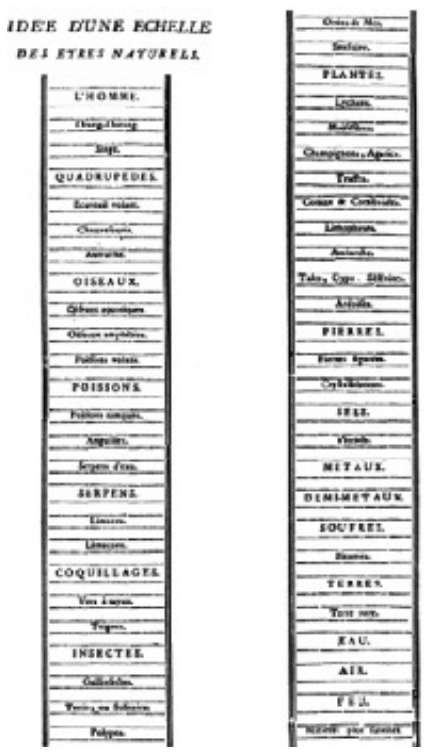

Figure 4. Scale of natural beings, according to Charles Bonnet (1745)

Charles White (1728-1813), a distinguished British doctor, published in 1799 his Regular Gradation in Man, where he presented the diversity of vertebrates in a linear gradation that goes from birds to crocodiles and dogs, passing through monkeys and ends in the human groups with the Caucasian model on the top. These are his words: «In who, but the European, could we find the arched noble head containing a similar quantity of brain (...)? And the perpidencular face, prominent nose, rounded chin? The variety of features and perfection of expressions (...) the rosy face and coralinian lip?» (White, 1799).

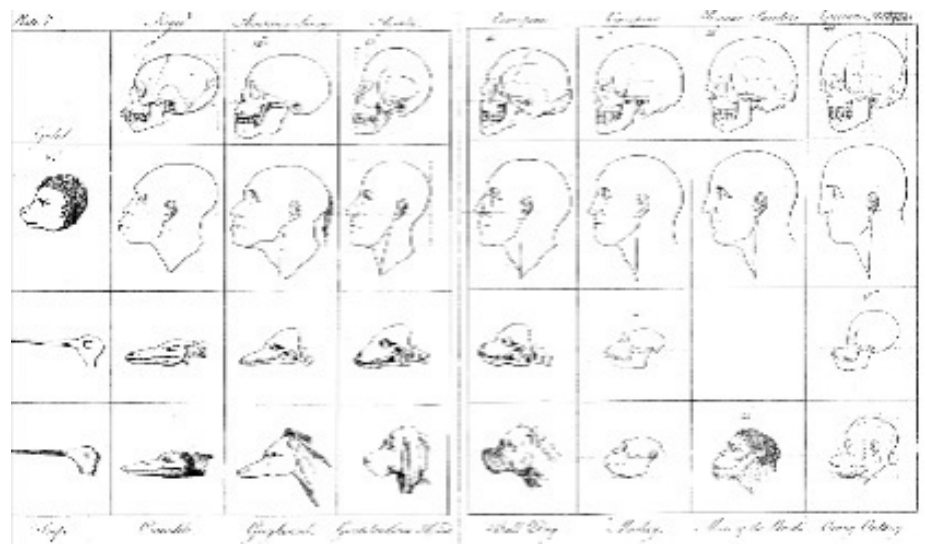

Figure 5. Linear gradation of vertebrate, according to Charles White (1799) 
This tradition of placing man at the top, in a clear vision of the world based on the mental scheme of "us and the others», has never disappeared. Even with Darwin, and especially after Darwin, this human inevitability and superiority ends up being a part of the structuring of Western thought. A canonical representation of evolution based on the principle that life starts with the simple and restrict and progresses always vertically to more and better was then produced and popularized. In this sense, evolution becomes synonym of progression. We find in Henry Fairfield Osborn (18571935), a North-American geologist, a good example of this type of representation. In the progressive evolution of the human brain, Osborn represents the brain of a chimpanzee as the least evolved, followed by Pitechanthropus, Piltdown, Neanderthal, and finally Homo sapiens, as the most evolved. The progression is revealed in terms of the volume of cerebral mass, this means, it starts with the smallest and most simple and progresses into more and more complex, and thus, better.

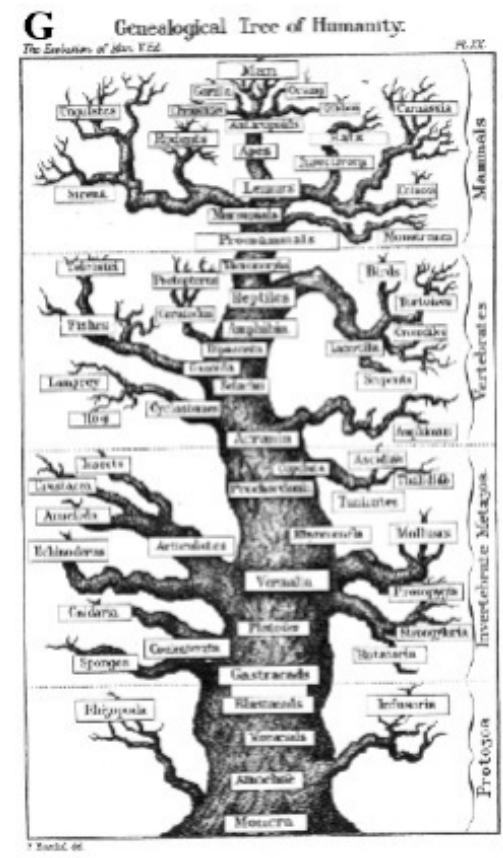

Figure 6. Genealogical tree of humanity, by Ernst Haeckel (1874)

Ernst Haeckel (1834-1919), brilliant promoter of Darwin's theory and his correspondent, in his work Anthropogenie (1874) included a genealogical tree of humanity. In this tree we find once more the canonical representation of evolution, this means, at the base of the tree the most simple beings and at the top the most complex. Furthermore, he hierarchies groups - protozoa, invertebrate metazoans, vertebrate, mammals - creating an order that gives a certain idea of ascendant movement, a progression that has the end at the top. 

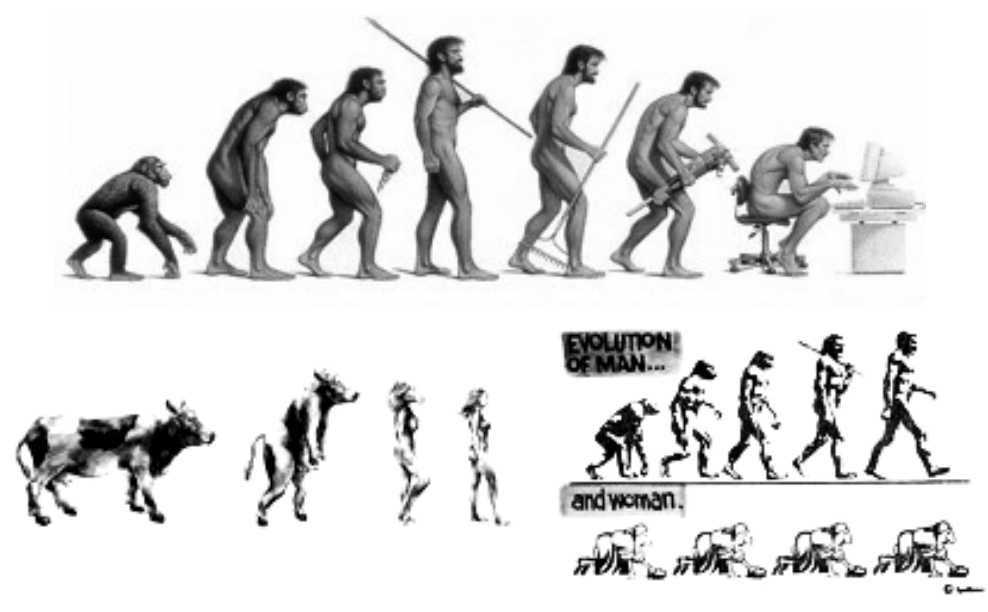

Figure 7. Set of illustrations representing the march of progress ${ }^{1}$

But even now we keep using this kind of iconography. The march of progress turned itself into a marketing concept. Evolution is progress and therefore the march is the trail that evolution has to walk towards a state of near perfection. This means that man is in the frontline of the evolution process. Behind him are all the others and, in front of him, nothing. These common iconographies of evolution are taken so serious that they end up being used in daily folklore, with immediate effects on the apprehension of the concept by the public. And they are even used in the representation of prejudices, stereotypes, and sexist jokes (fig. 4).

\section{Álvaro Cunhal: notes on Darwin’s work}

Álvaro Cunhal (1913-2005), a distinguished Portuguese politician of the $20^{\text {th }}$ century developed a careful critical analysis of Darwin's main ideas. In a letter dated October $6^{\text {th }} 1951$, censured by the country's dictatorial regime of the time, Cunhal complains about «the true campaign of silence on Darwin's work» that was established in Portugal and advances with an explanation for such situation: «Such campaign of silence can be understood. Evolutionism in biological sciences (as well as in geology), without taking into consideration all it affirms and implicates about the origin of man and the world, brings (however with Darwin's intention) the particularly undesirable idea that human societies also evolve; also in human societies nothing is permanent and eternal» (Cunhal, 2007). Furthermore, Cunhal criticises the limitations of Darwin in analyzing man's social life and intellectual activity: «Responding to an author who had offered him a fundamental work on political economy, Darwin

\footnotetext{
${ }^{1}$ Despite all efforts, it was not possible to identify the source of these images. But because of its importance we decided to include them here. To the author(s) we express our sincere apologies.
} 
wrote that he was only a naturalist and nothing understood of those issues... The answer was not sincere, because Darwin had drank from Malthus his Struggle for life and his "natural selection". However, that response explains his impossibility to see beyond the closed horizon of his extract. (...) Thus, his inability to understand that quantitative transformations alter into qualitative, and the consequential evolution in abrupt leaps, in the biological, as well as social field. From here we can appreciate his despise for "savages", his racism, his antifeminism, his marked British and whig spirit. Only ideologists of a new and ascending extract could, and did, break these limitations, overcome these difficulties and solve the problem of the evolution of man as a distinct evolution (from the moment he created and used work instruments) from the evolution of other living species. Darwin could not achieve that: from that moment, man, with a conscious purpose, started to act on nature and transform it» (Cunhal, 2007). Karl Marx (1818-1883), in a letter sent to the German philosopher Friedrich Engels (1820-1895) dated June $18^{\text {th }} 1862$, wrote «(...) Darwin reconnaît chez les animaux et les plantes sa propre société anglaise, avec sa division du travail, sa concurrence, ses ouvertures de nouveaux marchés, ses 'inventions' et sa malthusienne 'lutte pour la vie'. C'est le bellum omnium contra omnes de Hobbes (...)» (Marx, 1862, quoted in Pereira, 2003), that is, for Marx, Darwin's work was no more than a mirror of the economic and social logic of Victorian England.

Cunhal and Marx demand a certain social perspective from Darwin that would somehow correspond to a certain way of viewing the world. The connection of Darwin's ideas with the ideologies of Malthus is, for that reason, the identification of evolution with certain social issues, mainly the most polemical, which introduces a certain confusion of things, a confusion which ends up influencing the discursive folklore of our days. And so, the accusations, the prejudice and the fixations appear. Darwin is considered racist, antifeminist and the British people are considered to have an evil spirit.

\section{Conclusion}

John Gray, a charismatic British thinker, published in 2002 a brilliant book, entitled Straw Dogs. Thoughts on Humans and Other Animals. In the preface of the soft cover edition, Gray wrote the following: "Darwin's theory would not light up such a scandal if it had been formulated in a Hindu India, Taoist China or Animist Africa. In the same manner, it is only in the post Christian cultures that philosophers dedicate themselves so devotedly to the reconciliation of scientific determination with the belief in the exclusive ability of human beings to chose their way of living. The irony of the Evangelic Darwinism is that it uses science to corroborate a vision of humanity which comes from religion» (Gray, 2002). This same thinker makes a strong criticism to humanism in this book, considering it only a metamorphosis of Christian doctrine. In this sense, Gray considers humanism not a science, but a religion, this means, a belief that humans can make a world better than the one they have lived in until now. It is precisely due to this utopia that humanists seek Darwin to fundament their faith in progress, forgetting that the idea of progress is a secular belief of the Christian belief in Providence, and that, paraphrasing Karl Kraus, is condemned from the beginning to «celebrate Pyrrhic victories over nature». 
Darwin showed us a world where there is no progress. To insist on a connection between science and progress is to use abusively science for dangerous social means, not only because man will never live in a world created by himself, but because it erodes the foundation of scientific knowledge. This corrosion leaves science susceptible to a hostile environment leading to the appearance of anti-scientific movements which proliferate in later sections with very specific missions.

The reason why people are against evolution is not because of science. The reason why people are against evolution or resist to its arguments, is because they think evolution, as it was taught to them, represents a way of life constitutionalised in a certain political, social and economical system. That was exactly what happened with Cunhal, Marx, Engels, among others. On the one hand, they saluted the possibility of change, but on the other criticized what it was, in the end, an interpretation of themselves, of something that was intrinsically sterile in terms of ideology. In this sense, what is in debate is not evolution as a scientific fact, but a certain social perspective, a certain vision on the way we live in our daily life. The confusion of things remains in the fact that evolution is not perceived as a science, but as a representation of a certain way of life that we can after consider good or bad, this is, that can then be submitted to moral judgement. It is precisely for this reason that debating with creationists, for example, is completely useless, because it is a debate which will not make any difference to evolution: only arbitrary points of view are discussed on a certain way of life of human beings and, as Jacob (1981) well noted, «nothing is so dangerous as the certainty of being right».

\section{Bibliography}

AVELAR, Teresa; MATOS; Margarida \& REGO, Carla. Quem Tem Medo de Charles Darwin? O Problema da Selecção Natural. Lisboa: Relógio d'Água Editores, 2004

BONNET, Charles. Traité d'Insectologie, premier parte. Paris: Durand, 1745

BROWNE, Janet. Darwin's Origin of Species - A Biography. 2006 (Portuguese Translation by Ana Falcão Bastos and Cláudia Brito. Lisboa: Gradiva, 2008)

CUNHAL, Álvaro. Obras Escolhidas de Álvaro Cunhal. 1935-1947. Tomo I. Lisboa: Edições Avante, 2007

DENNETT, Daniel. Darwin's Dangerous Idea. 1995 (Portuguese Translation by Álvaro Augusto Fernandes. Lisboa: Temas e Debates, 2001)

GRAY, John. Straw Dogs. Thoughts on Humans and Other Animals. Granta Publications, 2002. (Portuguese Translation by Miguel Serras Pereira, Lisboa: Lua de Papel, 2007)

HAECKEL, Ernst. Antropogenie: Keimes-und Stammes Geschichte des Menschen. Leipzig: Engelmann, 1874

JACOB, François. The Possible and the Actual. Pantheon Books, 1981 (Portuguese Translation by Luis J. Archer. Lisboa: Gradiva, 1981)

PEREIRA, Ana Leonor. Darwin em Portugal [1865-1914]. Filosofia. História. Engenharia Social. Coimbra: Livraria Almedina, 2001

PINTO-CORREIA, Clara. O Mistério dos Mistérios. Uma História breve das teorias de reprodução animal. Lisboa: Relógio d’Água Editores, 1999

WHITE, Charles. An account of the Regular Gradation in Man, and in Different Animals and Vegetables; and from the Former to the Latter. London, 1799 